\title{
The Integration between USA Economy and Other World Countries Economies: Is the Financial Crisis Claiming Causality
}

\author{
Hussein Mohammad Salameh \\ College of Banking and Financial Sciences, Arab Academy for Banking and Financial Sciences, Jordan \\ P.O.Box 13190 Amman 11942 Jordan \\ E-mail: HSalameh@aabfs.org \\ Raed Jaber
}

Vice President for financial affairs, Arab Academy for Banking and Financial Sciences, Jordan

Bashar Al-Zu'bi

Senior Advisor to the CEO, Jordan Investment Board - Visiting Assistant Professor at University of Jordan

Received: February 27, $2011 \quad$ Accepted: March 9, $2011 \quad$ doi:10.5539/ijef.v3n5p187

\begin{abstract}
The integration between developed countries and developing ones is attracting the attention of the economic and finance people alike. The level of this integration has been more highlighted through the impact of the financial crisis on the United States economy and its reflection on regions and countries around the world. In this paper we employ econometric model and causality test to investigate if external shocks originated from the US economy play a pivotal role in influencing the macroeconomic fluctuations in different regions and countries around the world. The results show that the US economy is correlated with most of regions, but not with many individual countries; the US economic growth causes only the growth of 13 economies and 2 aggregate regions. This implies that the United States was not that successful in leading the campaign to persuade much of the world to follow its economic style.
\end{abstract}

Keywords: GDP, Unites States, Granger Causality, OLS Regression, Financial Crisis

\section{Introduction}

The global financial crisis has spread rapidly since the fall of 2008, leading to a global downturn of uncertain harshness and length. The impact of global financial crisis on real economy or production has become increasingly evident, spreading beyond its initials to affect almost all classes of economies; the advanced economies, emerging markets, and LDCs.

The impact of the global financial crisis is causing a considerable slowdown in most developed and developing countries. Stock markets are down more than $40 \%$ from their recent highs, investment banks have collapsed, interest rates have been cut around the world, leading indicators, such as GDP of global economic activity is declining. With a recession already underway in the UK, Germany, France, the USA and other developed countries, growth performance vary substantially among world regions and countries (Velde, 2008). While for many developing countries the effects of the crisis have lagged the rest of the world, its eventual impact is considered a severe one. Some developing countries witnessed a strong growth rate at the beginning of the crisis, but in a later stage these countries have been downgraded.

It can be stated that the repercussions of crisis that began in the United States are global. Anger was mounting over the global spillover effect of the U.S. crisis. Velde (2008) indicated that the impact of the US economy represented by the GDP as an economic indicator on regions and countries around the world economy has many channels, these include: trade and trade prices, remittances, foreign direct investment (FDI) and equity investment. In addition, the commercial lending, aid and other official flows are also considered among the channels. Each of these channels needs to be monitored, as changes in these variables have direct consequences on growth and development. It can be illustrated from the above that the linkages are generally not weak, and the second-round effects of the economic slowdown on the financial system is particularly severe.

Velde (2008) indicated that the list of channels above suggests that several countries are most likely affected by the crisis; Mexico's exports are mostly absorbed by the US, Zambia would eventually be hit by lower copper prices, and the tourism sector in Caribbean and African countries will be hit. Indian workers in the city of London will have less to remit. South Africa cannot afford to reduce its interest rate, and it has already missed some important FDI deals. 
India has seen a devaluation as well as high inflation. Import values in other countries have already weakened the current account. Countries with sophisticated stock markets and banking sectors with weakly regulated markets for securities are affected and countries dependent on aid are affected as well.

Based on the above, many important questions can be raised in this regard; is the worst financial crisis since the great depression claiming a casualty? Do shocks stemming from the U.S. indeed play a key role in driving domestic output fluctuations? The purpose of the paper is to address these questions. Many IMF studies for example, investigates whether the US shocks affect economic fluctuations in some major areas in the world such as East Asia, Latin America, and Sub-Saharan Africa using various empirical methods. However, up to our knowledge, most of the IMF studies and many other studies (such as K., et al., 2009) cover certain countries or regions. In addition, these studies cover the period during the 1980s, the 1990s and the 2000s, and could not fully catch the effect of the recent economic crises experienced by many countries in different parts of the world collectively.

In this paper we focus on the linkages between the U.S. and world countries economies, trying to shed some light on the potential spillovers and channels of transmission underlying them. This paper builds on the literature in several ways: First, we put emphasis on the magnitude of the responses of the GDP of different countries around the world to the shock using econometric techniques. We use the GDP, in level or growth rate, as it is one of the most commonly used indicators that reflect the state of a country's economy. As for our second contribution, this paper is able to add so many countries and several years more data to the analysis. By including high number of countries and the most recent period, the analysis can provide some clues regarding the causality of the recent US economy slowdown on different world economies.

The rest of the paper is organized as follows: section two shows the literature review. In section three, we specify the methodology, in particular the Granger Causality and the OLS regression. The empirical results are presented in section four, and section five concludes.

\section{Literature Review}

For the last decade, there has been much research in the integration and contagion between the US capital market and countries' markets around the world. Few research concentrate on the relationship and causality between US economy and countries' economics around the world. In this section we review the narrations of these articles. Calvo \& Reinhart (1996) find that there is increased comovement across weekly equity and Brady bond returns for emerging markets in Latin America after the Mexican crisis. It has been also indicated that international capital movements are all significantly affected by swings in interest rates in the United States. Finally, smaller Latin American countries appear to be affected more by developments in a core set of countries in a region than by developments in a single country. Staying in Mexico, Sosa (2008) finds that U.S. shocks explain a large share of Mexico's macroeconomic fluctuations after NAFTA. This partly reflects greater trade integration.

Discussing the impact on Latin American countries, Triner \& Wandschneider (2005) find a role for international contagion of financial crisis from Argentina to Brazil through testing the hypothesis that the Argentine financial failure in November 1890 was an important determinant of the Brazilian crisis. They also find that International disruptions compounded domestic financial weakness, rendering crisis inevitable for Brazilians. From their side, Futhermore and Kadil (2009) find that fluctuation in U.S. GDP growth have spillover effects that stimulate real growth and accelerate price inflation across Latin America and the Caribbean. These spillover effects are private consumption, private investment, growth of exports and imports, trade and current account balance.

Turning to other part of the world, Jithendranathan \& Kravchenko (2002) indicate that the Russian markets have become less volatile after the financial crisis of 1998. But the financial crisis had statistically significant positive effect on the Russian equity returns. The integration of the Russian equity market with the world equity market increased during the three-year post crisis period. Further discussion of the effect on the developed countries, Lucey, Nejadmalayeri \& Singh (2003) show that residual returns and conditional volatilities in major developed economies are significantly impacted by US macroeconomic surprises. They identify U.S. macroeconomic shocks that have spillover impact on global asset returns over and above those transmitted through equity market returns. While return levels are significantly influenced by productivity and retail sales surprises, return conditional volatilities are mainly influenced by inflation, personal income, industrial production, leading indicators, and gross domestic product surprises.

Moving to highlight the impact on the developing as well as developed countries, Awad, (2008) find that US growth in GDP affect growth in GDP in developing and G7 aggregate regions while it does not affect growth in GDP in Middle East region. Furthermore, Aizenman, J. \& Jinjarak, Y. (2008) find that an increase in the lagged US current account deficit is associated with an increase of current account surpluses of countries running surpluses, but with insignificant changes of current account deficits of countries running deficits. 
Moreover, Gouider (2010) finds that cross-sectional regressions show that external financial liberalization does not exert any significant effect on growth volatility in developed countries. However, in the case of emerging countries, freeing capital account movements is associated with higher output fluctuations. From their side, Zestos, Shaltayev \& Winder (2010) find that both central banks were found to succeed in affecting long-term interest rates and nominal GDP/output. U.S. monetary policy was found to affect (cause) nominal disposable personal income and to counter cyclically (correctly) react to changes in it.

Turning finally to Asia, Sato, Zhang, and McAleer, M. (2009) indicate that the real output variable and inflation rate are highly correlated and statistically significant among the Asian NIEs and during both the whole sample period and the period after the financial crisis. The US real output growth was correlated significantly with that in Japan, Taiwan, Malaysia and Thailand during the period 1978-1987, but maintained significant correlation only with that of Hong Kong, Singapore and Taiwan during the post-crisis period.

\section{Methodology}

In this study, we implement the followings:

Correlation between of U.S. GDP on Countries around the world GDP

Augmented Dickey-Fuller \& Phillips-Peron Unit Root to test the stationary of the series of GDP for each Country Ordinary Least Squares multiple regression to test the effect of U.S. GDP on Countries around the world GDP Granger Causality to test the relationship at the short run between U.S. GDP and Countries around the world GDP In part one of the current section, we describe data selection and data collection process. Part two describes the methodology of the unit root, while part three defines the model. Moving to part four we show the measurement of the variables (Gross Domestic Product (GDP)). In part five, we describe the methodology of granger causality.

\subsection{Data Description}

This study examines annual data relating to GDP listed in eight aggregate regions (United States, Arab Countries, Middle East and North Africa, East Asia, European Union, Australia, North America, Latin America \& Africa). The total number of sample countries is 95 countries distributed as follows: 17 Arab countries (Algeria, Iraq, Mauritania Morocco, Oman, Sudan, Syria, Kuwait, Bahrain, Libya, Yemen, Qatar, Emirates, Saudi, Jordan, Lebanon and Tunisia). From the MENA region, we have Israel. The sample contains 12 countries from East Asia (China, Hong Kong, India, Japan, Korea Rep, Malaysia, Philippines, Singapore, Sri Lanka, Thailand, Indonesia, Vietnam). 2 countries from middle Asia (Iran and Pakistan). 27 countries from the European Union \& European Continent (Belgium, Denmark, Finland, France, Greece, Ireland, Italy, Netherlands, Norway, Portugal, Spain, Swaziland, Sweden, Switzerland, Turkey, UK, Bulgaria, Cyprus, Croatia, Czech, Georgia, Slovenia, Germany, Hungary, Poland, Romania and Russian). Furthermore, we selected Australia and Canada from North America. Finally, 14 countries from Latin America and Caribbean have been selected (Bolivia, Brazil, Chile, Colombia, Ecuador, El Salvador, Honduras, Peru, Uruguay, Venezuela RB, Argentina, Paraguay, Mexico, Cuba), and 24 countries from Africa (Cameroon, Central Africa, Chad, Congo Dem, Congo, Costa Rica, Cote D'lvoire, Egypt, Gabon, Ghana, Jamaica, Kenya, Madagascar, Malawi, Nigeria, Senegal, South Africa, Zambia, Zimbabwe, Ethiopia, Mongolia, Gambi, Mali $\&$ Tongo).

The sample covers the period 1960 - 2009 as the data is available for most countries during this period, while the rest countries have data within the specified period. The data on GDP herein is collected from two main sources WB and International Financial Statistics (IFS) issued by the IMF.

\subsection{Unit Root Test}

The first step in the analysis is simply to look at the data univariate properties and to determine their integratedness degree. Theoretically a process is $\mathrm{I}(0)$, I(1) or I(2). The formal method to test a series is the unit root test. In this paper we use two widely unit root tests which are: Augmented Dickey-Fuller (ADF) test and the Phillips-Perron (PP) test (Note 1).

\subsection{The Model}

The equation of the model is:

Growth in GDP of individual country or aggregate region $=\alpha+\beta_{\mathrm{i}}$ Growth in GDP of the US

We test this model at two levels; first we investigate if the independent variable affects Growth in GDP of individual country, second we test if the independent variable affect growth in GDP of aggregate region. In both levels, we conduct the Ordinary Least Squares (OLS) regression. OLS is a mathematical approach used for prediction, the objective from this analysis is developing a statistical model to predict the dependent variable from the values of the 
independent variables. Also it is used to find if the independent variables have a significant effect on the dependent variable.

\subsection{Measurement of the variables}

GDP growth: $\left(\mathrm{GDP}_{\mathrm{t}}-\mathrm{GDP}_{\mathrm{t}-1}\right) / \mathrm{GDP}_{\mathrm{t}-1}$

Gross domestic product (GDP) at current prices: GDP is sum of gross value added, at purchaser prices converted at market exchange rates to current U.S. dollars, by all resident producers in the economy plus any product taxes (less subsidies) not included in the valuation of output. The total GDP data measured in current U.S. dollars using annual market exchange rates. This means that the values and derived rankings are subject to greater volatility due to variations in exchange rates. Inter-country comparisons based on GDP at market prices should, therefore, be treated with caution.

\subsection{Granger Causality Test}

The Granger (1969) approach to the question of whether $\mathrm{x}$ causes $\mathrm{y}$ is to see how much of the current $\mathrm{y}$ can be explained by past values of $y$, and then to see whether adding lagged values of $\mathrm{x}$ can improve the explanation. $\mathrm{Y}$ is said to be Granger-caused by $\mathrm{x}$ if $\mathrm{x}$ helps in the prediction of $\mathrm{y}$, or equivalently if the coefficients on the lagged $\mathrm{x}$ 's are statistically significant. Note that two-way causation is frequently the case; $x$ Granger causes y and y Granger causes x. It is important to note that Granger causality measures precedence and information content but does not by itself indicate causality in the more common use of the term. In this paper, we apply the Granger Causality test to check if there is a short run relationship between the variables.

\section{Results}

This section provides the detailed results of this study. The first part shows the correlation results, while the second part provides unit root results. In part three, we discuss the OLS regression results. Finally the granger causality results are presented in part four

\subsection{Correlation}

We conduct a correlation analysis of the growth in GDP among the concerned economies and calculate the correlation coefficients. Table 1 shows that the US real output growth is correlated significantly with that in all the aggregate regions in this study except European Union. The regions which have correlation with US are Arab countries, MENA, East Asia, Africa, Latin America and in addition to Australia and Canada. And US real output growth is correlated significantly with that in the following regions \& countries:

[Insert Table 1]

\subsection{Results}

The prerequisite in applying the OLS regression and Granger Causality procedures is to make the unit root properties for the series. So this study used ADF statistics and PP statistics. The results show that the null hypothesis of the unit root has been rejected at level I(0) under both ADF and PP tests for most of the countries, apart from Saudi Arabia, Georgia, Slovenia, Romania, Russia and Ethiopia, where the results show that they are I(1), while for Libya and Czech the results indicate that they are I(2).

Table 2 shows that the maximum value for the adjusted $\mathrm{R}^{2}$ is $23.5 \%$; this indicates that there are other possible variables than the growth in US GDP which might provide better explanation for the growth of GDP in countries around the world. Furthermore, Table 2 indicates that there is no significant effect for the US GDP growth on the GDP growth of 33 countries and 5 regions. The countries are: Algeria, Oman, Libya, Saudi Arabia, Tunisia, Hong Kong, Japan, Korea, Singapore, Thailand, Finland, France, Ireland, Sweden, Turkey, UK, Hungary, Canada, Bolivia, Brazil, Chile, El Salvador, Honduras, Paraguay, Mexico, Cuba, Cameroon, Congo, Cote D'lvoire, Gabon, Kenya and South Africa. The 5 regions are: MENA, Arab region, East Asia, Latin America and Australia.

\section{[Insert Table 2]}

In table 3 we conduct the OLS regression on the first and second difference variables to avoid the unit root problems. The results indicate that there is no significant effect for the US growth on the GDP growth of Libya, Croatia, Romania and Russia as the P-value is less than 10\% (1-confidence level (90\%)). The coefficient of the growth in US GDP is positive for Libya, Romania and Russia, while it is negative for Croatia. As for the remaining countries, we can not reject the null hypothesis which indicates that there is no significant effect for the GDP growth of US on the GDP growth of Saudi Arabia, Czech, Georgia, Slovenia and Ethiopia.

[Insert Table 3]

Moving to table 4, the results indicate that the US GDP growth causes the growth in GDP at lag 1 in Algeria, Oman, 
Saudi Arabia, Israel, Hong Kong, Philippines, Iran, Finland, Norway, UK, Georgia and Ecuador, as the P-value for those countries is less than $10 \%$. The same is applied for the regions of MENA and Arab region. As for the remaining countries and regions, our results indicate that the US GDP growth does not cause the GDP growth at lag 1 as the P-value is more than $10 \%$ (1-confidence level $(90 \%))$.

[Insert Table 4]

Turning finally to table 5 , we conduct the granger causality on the first difference and second difference level of the variables to avoid the unit root problem. The results indicate that the US GDP growth causes the GDP growth at lag 1 in Croatia, Romania and Russian. In addition, the results indicate that the US GDP growth does not cause the GDP growth at lag 1 for the remaining regions and countries.

\section{[Insert Table 5]}

\section{Conclusions}

The integration between developed countries economies and developing economies is attracting the attention of the economical and financial scientist. The impact of financial crisis on the US economy and its reflection on regions and countries around the world economy has many channels particularly trade and trade prices, remittances, FDI and equity investment, commercial lending and aid. Empirically, little is known about the relationship between growth in GDP (as an economic indicator) in US and growth in GDP in countries and regions around the world. In this paper we encounter this concern through addressing the issue surrounding the direct implementation of the GDP as a benchmark for economic volatility index and suggest a way for getting around it. Our results show that the pattern of the correlation coefficients for the real output growth at the aggregate regional level is a reflection of the global integration during the whole period. But at the countries level, only 20 countries around the world correlated with the US economy. Furthermore, the growth of the US economy reflected on the growth in economies of 35 countries and 5 aggregate regions. Finally, our results indicate that the growth in US economy causes only the growth in economies of 13 countries and 2 aggregate regions at one year lag.

Based on these results, several points can be highlighted; first the U.S. economy (the largest economy in the world) is correlated and affects positively the aggregate regions economies more than the individual countries. However, our result implies that the US influence in the world is not that strong, and it is hard to conclude that shocks to different economies have become more globally originated. This might be basically due to the significant structural changes which have been implemented in these economies.

In this context, the main policy implication that can be drawn is that each economy has its specifications and characteristics that distinguish it from the rest of countries in the world. However, we cannot ignore the fact that economies are correlated and connected through different channels. Over the past decades, the United States led the campaign to persuade many countries in the world, especially developing countries, to follow their model of capitalism. However, our results indicate that the United States has not been held up as a global economic model. In many developing countries, financial systems still remain far from the American style as it is more governed by the state, despite pressure from the United States to shift power to the private sector and create liberalized financial markets. Furthermore, the crisis has reinforced the fact that by now the change could shift the balance of how governments around the globe conduct free enterprise. Finally, more attention should be given on studying the contagion between the economies. As a continuation of this study, further research should be carried out using different measures for macroeconomic fluctuations.

\section{References}

Aizenman, J. \& Jinjarak , Y. (2008). The US as the "Demander of Last Resort" and its Implications on China's Current Account, NBER Working Paper No. W14453. http://papers.ssrn.com/sol3/papers.cfm?abstract_id=1294128.

Awad, T. (2008). The Effect of the Global Financial Flucatation on the Emerging Markets, Economic Observatory, Working Paper. http://www.ju.edu.jo/Resources/EconomicObservatory/Research\%20Output\%20Files

Calvo, S. \& Reinhart, C. (1996). Capital Flows to Latin America, Is there evidence of Contagion Effects?, Policy Research Working Paper. http://ideas.repec.org/p/wbk/wbrwps/1619.html.

Gouider, A. (2010). On the Importance of External Financial Reform for Output Fluctuations: Evidence from Developed and Emerging Economies, working paper. http://www.ps2d.net/media/Larnaout.pdf.

Jithendranathan, T., \& Kravchenko, N. (2002). Integration of Russian Equity Markets with the World Equity Markets - Effects of the Russian Financial Crisis of 1998, EFMA 2002 London Meetings. http://papers.ssrn.com/sol3/papers.cfm?abstract_id=314374.

Kadil, M. (2009). Spillover Effects of U.S. Business Cycles on Latin America and the Caribbean, Journal of 
Economic Issues, Vol. XLIII no. 4. http://ideas.repec.org/a/mes/jeciss/v43y2009i4p971-996.html.

Lucey, B., Nejadmalayeri, A. \& Singh,M. (2003). Impact of US Macroeconomic Surprises on Stock Market Returns in Developed Economies, SSRN Working Paper. http://ideas.repec.org/p/iis/dispap/iiisdp240.html.

Okubadejo, G. \& Adekeye, O. ( 2010). Can Understanding World Gross Domestic Product Enhance Efficient Global Investing? , working paper. http://papers.ssrn.com/sol3/papers.cfm?abstract_id=1652359

Sato, K., Zhang, Z. and McAleer, M. (2009). The Effect of External Shocks on Macroeconomic Fluctuations: Implications for a Monetary Union in East Asia, 18th World IMACS / MODSIM Congress, Cairns, Australia. http://www.mssanz.org.au/modsim09/D4/sato.pdf.

Sosa, S., (2008). External Shocks and Business Cycle Fluctuations in Mexico: How Important are U.S. Factors? International Monetary Fund. Working Paper. http://papers.ssrn.com/sol3/papers.cfm?abstract_id=1153722.

Triner, G. and Wandschneider, K. (2005). The Baring crisis and the Brazilian Encilhamento, 1889-1891: an early example of contagion among emerging capital markets, Financial History Review 12.2 (2005), pp. 199-225. doi:10.1017/S0968565005000107, http://dx.doi.org/10.1017/S0968565005000107

Velde, D. (2008). The global financial crisis and developing countries, Overseas Development Institute. [Online] Available: http://www.odi.org.uk/resources/download/2462.pdf. (Oct, 2008).

World Bank Sites: www.worldbank.org. http://databank.worldbank.org/ddp/home.do?Step=1\&id=4.

Zestos,, G. , Shaltayev, D. \& Winder, R., (2010), Empirical Evaluations of the U.S. and Canadian Monetary Policies and the Associated Causal Linkages, Journal of Business \& Economic Studies, Vol. 16, No. 1. http://www.dowling.edu/jbes/archive/spring2010/6.pdf.

Notes

Note 1. All tables which the unit root tests are available upon request.

Table 1.

\begin{tabular}{|c|c|c|c|c|c|c|c|}
\hline \multicolumn{8}{|c|}{ Correlation with the growth in GDP in US } \\
\hline Country & Cor. & Country & Cor. & Country & Cor. & Country & Cor. \\
\hline Arab Countries & $0.356^{* *}$ & Africa & & $\begin{array}{l}\text { European } \\
\text { Union }\end{array}$ & 0.268 & Latin America & $0.419 * * *$ \\
\hline Algeria & $0.423 * * *$ & Cameroon & $0.385 * * *$ & Belgium & 0.218 & Bolivia & 0.243 \\
\hline Iraq & 0.217 & Central Africa & 0.144 & Denmark & 0.239 & Brazil & 0.271 \\
\hline Mauritania & 0.112 & Chad & 0.015 & Finland & 0.274 & Chile & $0.295 * *$ \\
\hline Morocco & 0.087 & Congo Dem. & 0.086 & France & 0.244 & Colombia & 0.210 \\
\hline Oman & 0.260 & Congo & 0.276 & Greece & 0.204 & Ecuador & 0.206 \\
\hline Sudan & 0.115 & Costa Rica & 0.206 & Ireland & 0.243 & El Salvador & 0.262 \\
\hline Syria & 0.171 & Cote D'lvoire & 0.255 & Italy & 0.231 & Honduras & $0.318 * *$ \\
\hline Kuwait & 0.177 & Egypt & 0.034 & Netherlands & 0.220 & Peru & -0.041 \\
\hline Bahrain & 0.109 & Gabon & $0.290 * *$ & Norway & $0.333 * *$ & Uruguay & 0.186 \\
\hline Libya & $0.510^{* *}$ & Ghana & -0.011 & Portugal & 0.141 & Venezuela RB & 0.092 \\
\hline Yemen & 0.246 & Jamaica & -0.061 & Spain & 0.220 & Argentina & 0.085 \\
\hline Qatar & 0.155 & Kenya & 0.279 & Swaziland & 0.177 & Paraguay & 0.340 ** \\
\hline Emirates & 0.236 & Madagascar & 0.057 & Sweden & $0.287 * *$ & Mexico & $0.422 * * *$ \\
\hline Saudi & $0.317 * *$ & Malawi & -0.022 & Switerland & 0.215 & Cuba & $0.369 * *$ \\
\hline Jordan & 0.216 & Nigeria & 0.057 & Turky & 0.278 & & \\
\hline Lebanon & -0.292 & Senegal & 0.053 & UK & $0.363 * *$ & East Asia & $0.407 * * *$ \\
\hline \multirow[t]{2}{*}{ Tunisia } & 0.280 & South Africa & 0.277 & Bulgaria & -0.048 & China & -0.133 \\
\hline & & Zambia & 0.123 & Cyprus & -0.049 & Hong Kong & $0.460 * * *$ \\
\hline MENA & $0.368 * *$ & Zimbabwe & -0.007 & Croatia & 0.122 & India & 0.079 \\
\hline Israel & 0.111 & Ethiopia & -0.133 & Czech & 0.285 & Japan & $0.384 * * *$ \\
\hline North America & & Mongolia & -0.034 & Georgia & 0.175 & Korea Rep. & $0.442 * * *$ \\
\hline Canda & $0.501^{* *}$ & Gambia & 0.238 & Slovenia & 0.244 & Malaysia & $0.406^{* * *}$ \\
\hline \multirow[t]{2}{*}{ Australia } & $0.306^{* *}$ & Mali & 0.056 & Germany & 0.230 & Philippines & 0.238 \\
\hline & & Tongo & 0.249 & Hungary & 0.287 & Singapore & $0.425^{* * *}$ \\
\hline Middle Asia & & & & Poland & 0.113 & Sri Lanka & -0.137 \\
\hline Iran & 0.238 & & & Romania & 0.273 & Thailand & $0.344 * *$ \\
\hline \multirow{2}{*}{ Pakistan } & 0.075 & & & Russian & 0.180 & Indonesia & 0.208 \\
\hline & & & & & & Vietnam & -0.205 \\
\hline
\end{tabular}


Table 2.

\begin{tabular}{|c|c|c|c|c|c|c|c|c|c|}
\hline \multicolumn{10}{|c|}{ Ordinary Least Squares Regression with the growth in GDP in US } \\
\hline Country & Adjusted $\mathrm{R}^{2}$ & $\beta$ & t value & P val. & Country & $\begin{array}{l}\text { Adjusted } \\
\mathrm{R}^{2}\end{array}$ & $\beta$ & $\mathrm{t}$ value & P val \\
\hline Arab Countries & 0.104 & $1.977^{* *}$ & 2.377 & 0.022 & Latin America & 0.158 & $1.318^{* * *}$ & 3.168 & 0.003 \\
\hline Algeria & 0.161 & $2.137 * * *$ & 3.199 & 0.002 & Bolivia & 0.039 & $1.075^{*}$ & 1.719 & 0.092 \\
\hline Iraq & 0.027 & 1.943 & 1.521 & 0.135 & Brazil & 0.054 & $1.377^{*}$ & 1.930 & 0.060 \\
\hline Mauritania & -0.008 & 0.485 & 0.773 & 0.443 & Chile & 0.068 & $1.719^{* *}$ & 2.116 & 0.040 \\
\hline Morocco & -0.014 & 0.303 & 0.597 & 0.553 & Colombia & 0.024 & 0.820 & 1.471 & 0.148 \\
\hline Oman & 0.048 & $3.325^{*}$ & 1.848 & 0.071 & Ecuador & 0.022 & 0.960 & 1.443 & 0.156 \\
\hline Sudan & -0.008 & 0.683 & 0.795 & 0.431 & El Salvador & 0.049 & $0.542 *$ & 1.861 & 0.069 \\
\hline Syria & 0.008 & 0.858 & 1.187 & 0.241 & Honduras & 0.082 & $0.830 * *$ & 2.296 & 0.026 \\
\hline Kuwait & 0.010 & 1.665 & 1.210 & 0.233 & Peru & -0.02 & -0.241 & -0.278 & 0.782 \\
\hline Bahrain & -0.025 & 0.356 & 0.572 & 0.572 & Uruguay & 0.014 & 1.318 & 1.299 & 0.200 \\
\hline Libya & 0.217 & $5.020^{* *}$ & 2.446 & 0.026 & Venezuela & -0.013 & 0.513 & 0.636 & 0.528 \\
\hline Yemen & 0.005 & 1.745 & 1.044 & 0.311 & Argentina & -0.015 & 0.663 & 0.571 & 0.571 \\
\hline Qatar & -0.002 & 1.715 & 0.953 & 0.347 & Paraguay & 0.094 & $1.759 * *$ & 2.341 & 0.024 \\
\hline Emirates & 0.028 & 2.344 & 1.413 & 0.167 & Mexico & 0.161 & $2.205^{* * *}$ & 3.191 & 0.003 \\
\hline Saudi & 0.077 & $3.691 * *$ & 2.088 & 0.043 & Cuba & 0.113 & $1.141^{* *}$ & 2.412 & 0.021 \\
\hline Jordan & 0.024 & 0.858 & 1.434 & 0.159 & & & & & \\
\hline Lebanon & 0.037 & -2.169 & -1.333 & 0.198 & Africa & & & & \\
\hline \multirow[t]{2}{*}{ Tunisia } & 0.059 & $0.912 *$ & 1.982 & 0.053 & Cameroon & 0.130 & $1.567 * * *$ & 2.863 & 0.006 \\
\hline & & & & & Central Africa & 0.000 & 0.627 & 0.998 & 0.324 \\
\hline MENA & 0.114 & $1.856^{* *}$ & 2.475 & 0.018 & Chad & -0.021 & 0.077 & 0.103 & 0.919 \\
\hline \multirow[t]{2}{*}{ Israel } & -0.009 & 0.449 & 0.767 & 0.447 & Congo D. & -0.014 & 0.605 & 0.589 & 0.559 \\
\hline & & & & & Congo & 0.056 & $1.553 *$ & 1.965 & 0.055 \\
\hline $\begin{array}{l}\text { European } \\
\text { Union }\end{array}$ & 0.052 & 0.921 & 1.906 & 0.063 & Costa Rica & 0.022 & 0.867 & 1.445 & 0.155 \\
\hline Belgium & 0.027 & 0.823 & 1.532 & 0.132 & Cote D'lvoire & 0.045 & $1.155^{*}$ & 1.809 & 0.077 \\
\hline Denmark & 0.037 & $0.875^{*}$ & 1.689 & 0.098 & Egypt & -0.02 & 0.111 & 0.233 & 0.817 \\
\hline Finland & 0.055 & $1.111^{*}$ & 1.954 & 0.057 & Gabon & 0.065 & $2.359 * *$ & 2.078 & 0.043 \\
\hline France & 0.04 & $0.909^{*}$ & 1.727 & 0.091 & Ghana & -0.021 & -0.066 & -0.079 & 0.938 \\
\hline Greece & 0.021 & 0.663 & 1.428 & 0.160 & Jamaica & -0.018 & -0.263 & -0.417 & 0.679 \\
\hline Ireland & 0.039 & $0.836^{*}$ & 1.714 & 0.093 & Kenya & 0.058 & $1.071^{*}$ & 1.989 & 0.053 \\
\hline Italy & 0.033 & 0.852 & 1.627 & 0.110 & Madagascar & -0.018 & 0.249 & 0.390 & 0.698 \\
\hline Netherlands & 0.028 & 0.811 & 1.549 & 0.128 & Malawi & -0.021 & -0.128 & -0.152 & 0.880 \\
\hline Norway & 0.092 & 0.979 & 2.424 & 0.019 & Nigeria & -0.018 & 0.453 & 0.394 & 0.695 \\
\hline Portugal & -0.001 & 0.534 & 0.977 & 0.334 & Senegal & -0.018 & 0.228 & 0.361 & 0.720 \\
\hline Spain & 0.028 & 0.934 & 1.545 & 0.129 & S. Africa & 0.057 & $1.298^{*}$ & 1.977 & 0.054 \\
\hline Swaziland & 0.011 & 1.012 & 1.232 & 0.224 & Zambia & -0.006 & 0.763 & 0.847 & 0.401 \\
\hline Sweden & 0.063 & $1.067 * *$ & 2.057 & 0.045 & Zimbabwe & -0.021 & -0.058 & -0.049 & 0.961 \\
\hline Switzerland & 0.026 & 0.844 & 1.508 & 0.138 & Ethiopia & -0.020 & -0.815 & -0.686 & 0.499 \\
\hline Turkey & 0.057 & $1.697^{*}$ & 1.982 & 0.053 & Mongolia & -0.037 & -0.349 & -0.173 & 0.864 \\
\hline UK & 0.113 & $1.267 * *$ & 2.670 & 0.010 & Gambia & 0.033 & 0.982 & 1.566 & 0.125 \\
\hline Bulgaria & -0.035 & -0.359 & -0.249 & 0.805 & Mali & -0.022 & 0.285 & 0.354 & 0.725 \\
\hline Cyprus & -0.035 & -0.184 & -0.255 & 0.801 & Tongo & 0.033 & 0.931 & 1.455 & 0.156 \\
\hline Croatia & -0.043 & 1.225 & 0.507 & 0.619 & & & & & \\
\hline Czech & 0.027 & 2.018 & 1.224 & 0.237 & East Asia & 0.148 & $1.187^{* * *}$ & 3.058 & 0.004 \\
\hline Georgia & -0.026 & 1.704 & 0.732 & 0.474 & China & -0.003 & -0.480 & -0.921 & 0.362 \\
\hline Slovenia & 0.004 & 1.768 & 1.037 & 0.314 & Hong Kong & 0.195 & $1.529 * * *$ & 3.551 & 0.001 \\
\hline Germany & 0.027 & 0.917 & 1.437 & 0.159 & India & -0.015 & 0.246 & 0.543 & 0.590 \\
\hline Hungary & 0.059 & $0.838^{*}$ & 1.870 & 0.069 & Japan & 0.129 & $1.625^{* * *}$ & 2.850 & 0.006 \\
\hline Poland & -0.032 & 0.828 & 0.532 & 0.600 & Korea Rep. & 0.178 & $2.538 * * *$ & 3.380 & 0.001 \\
\hline Romania & 0.028 & 2.175 & 1.270 & 0.219 & Malaysia & 0.147 & 1.637 & 3.042 & 0.004 \\
\hline \multirow[t]{2}{*}{ Russian } & -0.021 & 1.865 & 0.778 & 0.447 & Philippines & 0.037 & 1.026 & 1.679 & 0.100 \\
\hline & & & & & Singapore & 0.163 & $1.476^{* * *}$ & 3.220 & 0.002 \\
\hline \multirow[t]{2}{*}{ Australia } & 0.072 & $1.063^{* *}$ & 2.084 & 0.043 & Sri Lanka & -0.002 & -0.432 & -0.949 & 0.347 \\
\hline & & & & & Thailand & 0.100 & $1.163 * *$ & 2.513 & 0.015 \\
\hline N. America & & & & & Indonesia & 0.019 & 1.232 & 1.347 & 0.186 \\
\hline \multirow[t]{4}{*}{ Canda } & 0.235 & $1.145^{* * *}$ & 3.969 & 0.000 & Vietnam & -0.002 & -2.805 & -0.981 & 0.337 \\
\hline & & & & & & & & & \\
\hline & & & & & Iran & 0.034 & 1.518 & 1.590 & 0.119 \\
\hline & & & & & Pakistan & -0.015 & 0.276 & 0.517 & 0.607 \\
\hline
\end{tabular}


Table 3 .

\begin{tabular}{|c|c|c|c|c|c|c|c|c|c|}
\hline \multicolumn{10}{|c|}{$1^{\text {st }}$ Difference \& $2^{\text {nd }}$ Difference Ordinary Least Squares Regression with $1^{\text {st }}$ Difference $\& 2^{\text {nd }}$ Difference of the growth in GDP in US } \\
\hline Country & $\begin{array}{l}\text { Adjusted } \\
\mathrm{R}^{2}\end{array}$ & $\beta$ & t value & P val. & Country & $\begin{array}{l}\text { Adjusted } \\
\mathrm{R}^{2}\end{array}$ & $\beta$ & t value & P val. \\
\hline D2(Libya) & 0.218 & $8.003^{* *}$ & 2.335 & 0.034 & D2(Slovenia) & 0.048 & -4.207 & -1.341 & 0.200 \\
\hline D1(Saudi) & -0.025 & -0.617 & -0.211 & 0.834 & D1(Romania) & 0.094 & $3.625^{*}$ & 1.752 & 0.096 \\
\hline D2(Czech) & -0.032 & -1.930 & -0.706 & 0.491 & D2(Russian) & 0.199 & $8.585^{* *}$ & 2.283 & 0.036 \\
\hline D2(Croatia) & 0.273 & $-8.133 * *$ & -2.645 & 0.018 & D1(Ethiopia) & -0.040 & 0.119 & 0.084 & 0.934 \\
\hline D2(Georgia) & -0.062 & 0.738 & 0.247 & 0.808 & & & & & \\
\hline
\end{tabular}


Table 4.

\begin{tabular}{|c|c|c|c|c|c|c|c|}
\hline \multicolumn{8}{|c|}{ Granger Causality Test } \\
\hline \multicolumn{8}{|c|}{ Null Hypothesis: US does not Granger Cause ......... } \\
\hline Country Or Region & Obs & F-Statistic & Probability & Country Or Region & Obs & F-Statistic & Probability \\
\hline Arab Countries & 40 & $6.10613 * *$ & 0.0182 & European Union & & 1.54812 & 0.21986 \\
\hline ALGERIA & 48 & $9.78992 * * *$ & 0.00308 & BELGUIM & 48 & 0.47938 & 0.49226 \\
\hline Iraq & 48 & 2.47516 & 0.12266 & Denmark & 48 & 0.60597 & 0.44038 \\
\hline Mauritania & 48 & 0.0195 & 0.88957 & Finland & 48 & $4.12584 * *$ & 0.04816 \\
\hline Morocco & 48 & 1.17586 & 0.28398 & France & 48 & 0.85733 & 0.35943 \\
\hline Oman & 48 & $6.39612 * *$ & 0.01501 & Greece & 48 & 1.29608 & 0.26095 \\
\hline Sudan & 48 & 1.16234 & 0.28673 & Ireland & 48 & 1.78233 & 0.18858 \\
\hline Syria & 48 & 2.30305 & 0.13611 & Italy & 48 & 1.90451 & 0.17439 \\
\hline Kuwait & 46 & 0.56076 & 0.45803 & Netherlands & 48 & 0.87128 & 0.35558 \\
\hline Bahrain & 28 & 0.50869 & 0.48231 & Norway & 48 & $3.00585^{*}$ & 0.08981 \\
\hline Libya & 18 & 1.11905 & 0.30686 & Portugal & 48 & 0.9418 & 0.337 \\
\hline Yemen & 18 & 0.02632 & 0.8733 & Spain & 48 & 0.07397 & 0.78689 \\
\hline Qatar & 38 & 1.7147 & 0.19891 & Swaziland & 48 & 0.01204 & 0.91313 \\
\hline Emirates & 35 & 1.54553 & 0.22283 & Sweden & 48 & 0.67132 & 0.41691 \\
\hline Saudi Arabia & 40 & $5.19972 * *$ & 0.02845 & Switerland & 48 & 1.04764 & 0.31152 \\
\hline Jordan & 43 & 1.5928 & 0.21424 & Turkey & 48 & 1.07988 & 0.30428 \\
\hline Lebanon & 20 & 0.12851 & 0.72439 & UK & 48 & $3.15082 *$ & 0.08265 \\
\hline \multirow[t]{2}{*}{ Tunisia } & 47 & 1.69102 & 0.20024 & Bulgaria & 28 & $3.10 \mathrm{E}-05$ & 0.99561 \\
\hline & & & & Cyprus & 28 & 0.05248 & 0.82066 \\
\hline MENA & 40 & $6.16184 * *$ & 0.01772 & Croatia & 18 & 2.32668 & 0.14798 \\
\hline \multirow[t]{2}{*}{ Israel } & 48 & $4.59765 * *$ & 0.03745 & Czech & 18 & 0.11225 & 0.74223 \\
\hline & & & & Georgia & 18 & $4.28339^{*}$ & 0.05617 \\
\hline East Asia & 48 & 0.52951 & 0.47058 & Slovenia & 18 & 0.33907 & 0.56902 \\
\hline CHINA & 48 & 0.39541 & 0.53265 & Germany & 38 & 0.88811 & 0.35245 \\
\hline Hong Kong & 48 & $4.23163^{* *}$ & 0.0455 & Hungary & 40 & 0.92846 & 0.34152 \\
\hline India & 48 & 0.35144 & 0.55627 & Poland & 23 & 0.2944 & 0.59341 \\
\hline Japan & 48 & 0.2747 & 0.60277 & Romania & 21 & 0.72715 & 0.40501 \\
\hline Korea Rep. & 48 & 3.50261 & 0.06778 & Russian & 19 & 2.1353 & 0.1633 \\
\hline Malaysia & 48 & 1.7204 & 0.19629 & & & & \\
\hline Philippines & 48 & $4.38515 * *$ & 0.04192 & Africa & & & \\
\hline Singapore & 48 & 1.15904 & 0.2874 & Cameron & 48 & $3.47769^{*}$ & 0.06873 \\
\hline Sri Lanka & 48 & 0.04387 & 0.83505 & Central Africa & 48 & $5.2669 * *$ & 0.02645 \\
\hline Thailand & 48 & 0.44797 & 0.50672 & Chad & 48 & 0.22342 & 0.63873 \\
\hline Indonesia & 41 & 1.76864 & 0.19148 & Congo Dem. & 48 & 1.08763 & 0.30257 \\
\hline \multirow[t]{2}{*}{ Vietnam } & 23 & 0.49461 & 0.48999 & Congo Rep. & 48 & 1.73767 & 0.19411 \\
\hline & & & & Costa Rica & 48 & 0.22488 & 0.63764 \\
\hline Iran & 43 & $4.72475 * *$ & 0.03571 & Cote D'lvoire & 48 & 1.74912 & 0.19267 \\
\hline \multirow[t]{2}{*}{ Pakistan } & 48 & 2.21753 & 0.14343 & Egypt & 48 & 1.38189 & 0.24596 \\
\hline & & & & Gabon & 48 & 2.77327 & 0.1028 \\
\hline Latin America & 48 & 1.93706 & 0.17083 & Ghana & 48 & 0.04842 & 0.82683 \\
\hline BOLIVIA & 48 & 2.64084 & 0.11113 & Jamaica & 48 & 0.05165 & 0.82125 \\
\hline BRAZIL & 48 & 2.12056 & 0.15228 & Kenya & 48 & 0.73385 & 0.39618 \\
\hline CHILE & 48 & 0.02391 & 0.87782 & Madagascar & 48 & 1.19242 & 0.28065 \\
\hline COLOMBIA & 48 & 0.52152 & 0.47393 & Malawi & 48 & 0.0076 & 0.9309 \\
\hline Ecuador & 48 & $3.7538^{*}$ & 0.05898 & Nigeria & 48 & 1.35374 & 0.25076 \\
\hline El Salvador & 48 & 0.20563 & 0.65239 & Senegal & 48 & 0.791 & 0.37853 \\
\hline Honduras & 48 & 1.70005 & 0.19891 & South Africa & 48 & 0.07603 & 0.78402 \\
\hline Peru & 48 & 0.47716 & 0.49326 & Zambia & 48 & 0.02169 & 0.88358 \\
\hline Uruguay & 48 & 1.66172 & 0.20396 & Zimbabwe & 48 & 0.82976 & 0.36719 \\
\hline Venezuela RB & 48 & 1.70513 & 0.19826 & Ethiopia & 27 & 0.31529 & 0.57966 \\
\hline Argentina & 46 & 0.30495 & 0.58366 & Mongolia & 27 & 0.7379 & 0.39883 \\
\hline Paraguay & 43 & 2.09023 & 0.15603 & Gambia & 42 & $8.10707 * * *$ & 0.007 \\
\hline Mexico & 48 & 1.08124 & 0.30398 & Mali & 41 & 0.00883 & 0.92565 \\
\hline Cuba & 38 & 0.69094 & 0.41148 & Tongo & 33 & 0.13451 & 0.71638 \\
\hline North America & & & & Australia & 43 & 2.45891 & 0.12474 \\
\hline CANDA & 48 & 0.65794 & 0.42156 & & & & \\
\hline
\end{tabular}


Table 5 .

\begin{tabular}{|c|c|c|c|c|c|c|c|}
\hline \multicolumn{8}{|c|}{ Granger Causality Test } \\
\hline \multicolumn{8}{|c|}{ Null Hypothesis: $\quad$ DUS or D2US does not Granger Cause ...... } \\
\hline Country or Region & Obs & F-Statistic & Probability & Country or Region & Obs & F-Statistic & Probability \\
\hline DSAUDI & 39 & 2.458 & 0.126 & D2SLOVINIA & 16 & 1.026 & 0.330 \\
\hline D2LIBYA & 16 & 0.423 & 0.527 & DROMANIA & 20 & $5.659^{* *}$ & 0.029 \\
\hline D2CROATIA & 16 & $4.197 *$ & 0.061 & D2RUSSA & 17 & $3.343 *$ & 0.089 \\
\hline D2GEOGRIA & 16 & 1.555 & 0.234 & DETHOPIA & 26 & 0.028 & 0.867 \\
\hline D2CEZH & 16 & 0.645 & 0.436 & & & & \\
\hline
\end{tabular}

